\title{
EARLY PRENATAL DIAGNOSIS OF ISCHIOPAGUS CONJOINED TWINS
}

\author{
Ahmet Mete ERGENOGLU' ${ }^{1}$, Nuri YILDIRIM², Ahmet Ozgur YENIEL ${ }^{1}$, Ali AKDEMIR ${ }^{1}$, \\ Alkim Gulsah Sahingoz YILDIRIM ${ }^{1}$, Nedim KARADADAS ${ }^{1}$ \\ 1 Department of Obstetrics and Gynecology, Ege University School of Medicine, Istanbul \\ 2 Department of Obstetrics and Gynecology, Dokuz Eylul University School of Medicine, Istanbul
}

\begin{abstract}
SUMMARY
Conjoined twins are very rare and the incidence of them vary about $1 / 50.000$ and $1 / 100.000$. They are named according to the joint parts. Embryos are conjoined at the level of ischium in ischiopagus. A case of ischiopagus will be presented in this article.

A twenty-seven year old woman who is 9-10 weeks pregnant with a history of 1 abortus applied to the Ege University Department of Obstetrics and Gynecology for routine follow-up. Ultrasonography revealed a twin pregnancy but the embryos were attached at the pelvic region. 3D Doppler sonography confirmed the diagnosis of ischiopagus tetrapus. The patient's decision of termination of pregnancy is concluded at Perinatology Council of the clinic.

Ischiopagus conjoined twins are very rare. Early prenatal diagnosis will prevent the maternal complications during the termination of the pregnancy.
\end{abstract}

Key words: conjoined twins, ischiopagus, prenatal diagnosis

Journal of Turkish Society of Obstetrics and Gynecology, (J Turk Soc Obstet Gynecol), 2014; Vol: 11, Issue: 1, Pages: 68-70

\section{İSKIOFAGUS OLGUSUNDA ERKEN PRENATAL TANI}

\section{ÖZET}

Yapışık ikizler, 1/50.000 ile 1/100.000 arasında görülen nadir patolojilerdendir. İkizler, yapışma bölgesine göre isimlendirilirler. Bunlar içerisinde iskiofagus, fetusların iskial bölgeden yapışık olduğunu tarifler. Bu olgu sunumunda, bir iskiofagus olgusunun erken prenatal tanısı tartışılacaktır. 27 yaşında, 9-10 haftalık gebeliği olan ve 1 düşük öyküsü bulunan hasta rutin gebelik kontrolü için Ege Üniversitesi Kadın Hastalıklarl ve Doğum Kliniği'ne başvurmuştur. Burada yapılan ultrasonografisinde hastanın ikiz gebeliğinin olduğu, fetusların pelvik bölgeden yapışı oldukları saptanmış, üç boyutlu Doppler ultrasonografi ile iskiofagus tetrapus tanısı kesinleştirilmiştir. Perinatoloji Konseyinde ailenin gebeliğin sonlandırılması isteği uygun görülmüşürr.

İskiofagus yapışık ikizleri nadir görülen bir durumdur. Tanının erken dönemde konulması, gebelik terminasyonu sırasında anne ile ilgili gelişebilecek komplikasyonları en aza indirgeyecektir.

Anahtar kelimeler: iskiofagus, prenatal tanı, yapışık ikiz

Türk Jinekoloji ve Obstetrik Derneği Dergisi, (J Turk Soc Obstet Gynecol), 2014; Cilt: 11, Sayl: 1, Sayfa: 68-70

Address for Correspondence: Dr. Nuri Yıldırım. Dokuz Eylül Üniversitesi Tıp Fakültesi, Kadın Hastalıkları ve Doğum ABD, 35330 Balçova, İzmir Phone: + 90 (232) 4123139

e-mail: nuri-yildirim@hotmail.com

Received: 26 March 2013, revised: 13 August 2013, accepted: 18 August 2013, online publication: 19 August 2013 


\section{INTRODUCTION}

The incidence of conjoined twins is between 1/50.000 and $1 / 100.000$ in the literature ${ }^{(1)}$. In theory, conjoined twins are encountered when division of monozygotic twins is after $13^{\text {th }}$ day of the formation of the zygote. The most common types are thoraco-pagus, omphalopagus and thoraco-omphalofagus ${ }^{(1)}$. Ischiopagus describes two fetus conjoined at the level of the ischium as a definition, and is approximately $\% 12$ of conjoined twins ${ }^{(2)}$. In this case report, we are going to discuss a case which diagnosed at early prenatal period.

\section{CASE}

27 years old, G2P0 with a history of $7^{\text {th }}$ week abortion, applied to our clinic for routine follow-up. The patient had no additional medical problem; USG has had performed in 5-6 weeks of gestation in another center before. One gestational sac was seen, embryo was not observed. It was 9-10 weeks spontaneous pregnancy during the admission. There was no pathology in the patient's routine gynecological examination. One gestational sac and yolk sac were detected in 2D USG, as well as two cardiac activities. Embryos were examined carefully; two embryos were attached to each other at the level of the pelvis. But, both of the embryos have two upper and two lower extremities separately. It was seen that there was one umbilical cord at the Doppler examination. Each embryo has one artery and one vein which were coming from this umbilical cord (Figure 1). One bladder was seen belonged to two embryos. 3D USG confirmed ischiopagus (Figure 2). The family was informed for the possible problems which would happen during or after delivery. Family's request of the termination of pregnancy was found appropriate in Perinatology Council. After taking informed consents, pregnancy was terminated by induction of labor. Figure 3 shows he embryos after therapeutic abortion.

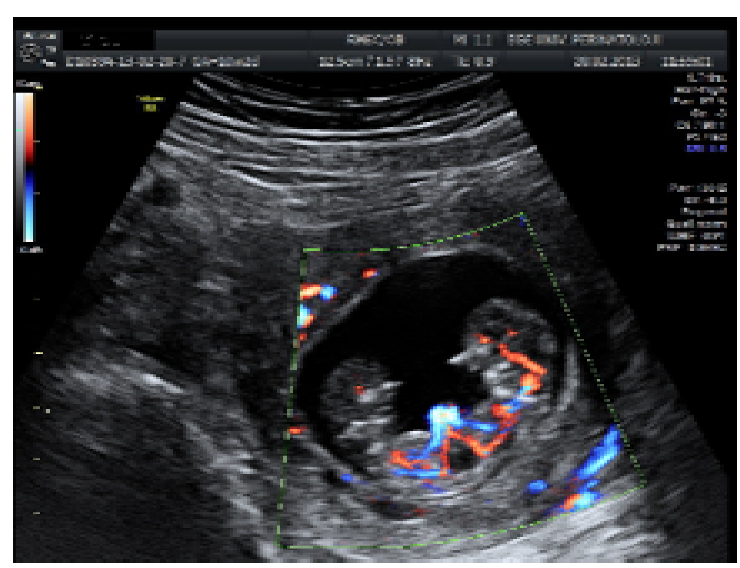

Figure 1: Color Doppler view of the ischiopagus. Single urinary bladder and single umbilical artery for each fetus is seen.

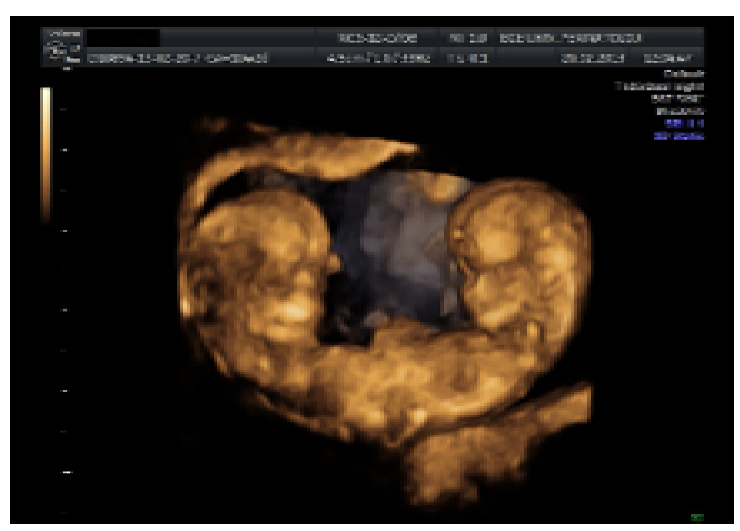

Figure 2: 3D Doppler view of the ischiopagus.

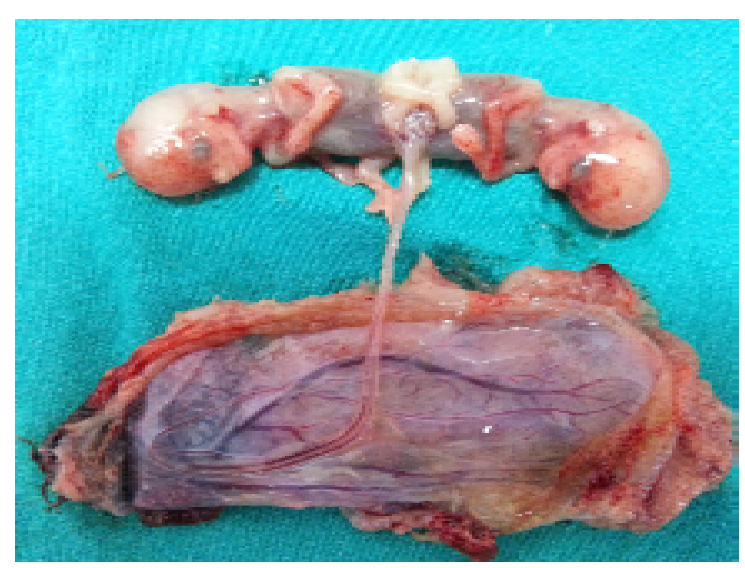

Figure 3: After the termination; the gestational age is $10 w 3 d$ in the ischiopagus case. 


\section{DISCUSSION}

Conjoined twins are rare cases. Because of the large number of the anomalies associated, these fetuses are lost in utero or in early postpartum period. Otherwise, when pregnancy reaches to term, very serious problems can arise related to childbirth. If the pathology can be diagnosed at prenatal period, termination may be an option according to gestational age. In the absence of intrauterine diagnosis, the situation is much more serious and delivery can threat mother's life as well as fetuses' lives.

Conjoined twins are named according to the region attached and the most common types are thoracopagus, omphalopagus and thoracoomphalopagus(1). Ischiopagus describes the status of being conjoined at the level of ischium. The state of the two fetuses who had three feet is tripus, four feet is tetrapus. This case is ischiopagus tetrapus.

Innovations in USG, which become a part of the daily practice of the obstetrics, allow early diagnosis of intrauterine pathologies. The early diagnosis of conjoined twins is really important in the management of the situation and reducing maternal mortality (evacuation, therapeutic abortus, hysterotomy). First trimester ultrasound findings of conjoined twins are fetal structures that can not be separated in spite of uterine manipulation, single yolk sac, images of splitted embryos, presence of more than 3 vessels in umbilical $\operatorname{cord}^{(3)}$. In the literature, there are publications about early diagnosis of conjoined twins with 3D USG, MRI and $\mathrm{CT}^{(4,5)}$. In this case, diagnosis was mad with $2 \mathrm{D}$ sonography and confirmed by 3D sonography.

A case report published by Fang et al. pointed out that the diagnosis of ischiopagus conjoined twins at 9 weeks of gestation was made by $2 \mathrm{D}$ and $3 \mathrm{D} \mathrm{USG}^{(6)}$. They asserted that, this method increases the reliability for early diagnosis and helps family to understand this complex abnormality. The literature about early diagnosis of these cases by using MRI or CT is limited by case reports. But MRI or CT are routinely used for operation of these cases after delivery. Turner et al remarked that MRI is superior to $\mathrm{CT}$, due to the lack of exposure to radiation during antenatal period ${ }^{(5)}$. Imaging methods, as technology advances, provides more opportunities to reach to diagnosis. Diagnosis of conjoined twins is hard and requires an experienced perinatologist should be noted. Especially monocorionic-monoamniotic conjoined twins make USG technically harder. USG in early weeks is really important.

As a result, ischiopagus is a rare type of conjoined twins. The early diagnosis of these cases is very important in terms of complications that may occur later. The early diagnosis decreases the complication rates of termination of pregnancy. One of the diagnostic methods, 3D Doppler USG, is effective method for better understanding of the family as the existing pathology and shows a way about continuation or termination of pregnancy.

\section{REFERENCES}

1. Edmonds LD, Layde PM. Conjoined twins in the united states, 1970-1977. Teratology 1982;25(3):301-8.

2. Verrier MD, Hastings CJ, Hoffman EB. Posterior iliac osteotomy in ischiopagus tetrapus twins. J Pediatr Orthop 2000;20(6):807-11.

3. Bromley B, Benacerraf B. Using the number of yolk sacs to determine amnionicity in early first trimester monochorionic twins. J Ultrasound Med 1995;14(6):415-9.

4. Benson RC, Colletti PM, Platt LD, Ralls PW. MR imaging of fetal anomalies. Am J Roentgenol 1991;156(6):1205-7.

5. Turner RJ, Hankins GD, Weinreb JC, Ziaya PR, Davis TN, Lowe TW et al. Magnetic resonance imaging and ultrasonography in the antenatal evaluation of conjoined twins. Am J Obstet Gynecol 1986;155(3):645-9.

6. Fang KH, Wu JL, Yeh GP, Chou PH, Hsu JC, Hsieh CT. Ischiopagus conjoined twins at 9 weeks of gestation: threedimensional ultrasound and power Doppler findings. Ultrasound Obstet Gynecol 2005;25(3):309-10. 